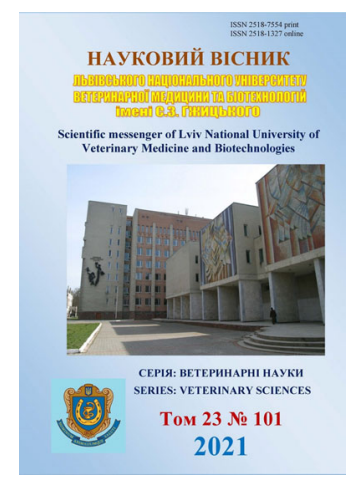

Науковий вісник Дьвівського національного університету ветеринарної медицини та біотехнологій імені С.3. Гжицького. Серія: Ветеринарні науки

\author{
Scientific Messenger of Lviv National University \\ of Veterinary Medicine and Biotechnologies. \\ Series: Veterinary sciences
}

UDC 619.615

\title{
The effect of the drug "Bendamin" on the biochemical parameters of the blood of dogs in heart failure
}

\author{
I. S. Varkholiak, B. V. Gutyj
}

Stepan Gzhytskyi National University of Veterinary Medicine and Biotechnologies Lviv, Ukraine

Article info

Received 20.01.2021

Received in revised form 22.02.2021

Accepted 23.02.2021

Stepan Gzhytskyi National University of Veterinary Medicine and Biotechnologies Lviv, Pekarskaya Str., 50, Lviv, 79010, Ukraine.

Tel. $:+38-096-486-26-85$

E-mail: irynkavet@ukr.net
Varkholiak, I. S., \& Gutyj, B. V. (2021). The effect of the drug "Bendamin" on the biochemical parameters of the blood of dogs in heart failure. Scientific Messenger of Lviv National University of Veterinary Medicine and Biotechnologies. Series: Veterinary sciences, 23(101), 93-99. doi: $10.32718 /$ nvlvet10116

Experimental studies obtained in recent years indicate the urgency of developing drugs of complex action to prevent the development of cardiovascular disease in dogs. This requires a much deeper study of the pathogenesis of heart failure, including cardiomyopathy. The aim of the study was to investigate the effect of the drug "Bendamin" on the biochemical parameters of the blood of dogs in heart failure. Two groups of dogs were formed for research: control (healthy) and experimental (sick). The 30-day experiment included 10 dogs of the control group and 10 dogs of the experimental (sick) breed of spaniel and dog 10-12 years of age. Treatment regimen for sick dogs: furosemide was administered orally on an empty stomach at $2 \mathrm{mg} / \mathrm{kg}$ every 12 hours; enalapril was administered orally at $0.5 \mathrm{mg} / \mathrm{kg}$ every 12 hours; bendamine was administered orally on an empty stomach at $20 \mathrm{mg} / \mathrm{kg}$ every 24 hours. It is recommended to divide the dose into two doses. An increase in the activity of aminotransferases (ALT by $59.2 \%, A S T-$ by $51.9 \%$ ) was found in the serum of dogs at heart failure. An increase in alkaline phosphatase activity was also found, which in the complex is an additional confirmation of changes in the heart muscle. Lactate dehydrogenase activity increased in the blood of sick dogs by $23.5 \%$. Minor changes in the content of total bilirubin and urea in the serum of sick dogs indicate the initial stage of liver pathology with impaired liver function due to congestion in the small circulation. This is also indicated by a decrease in the level of total protein in the blood of sick dogs, which was respectively $57.2 \pm 3.57 \mathrm{~g} / \mathrm{l}$ against the control group of $63.5 \pm 4.15 \mathrm{~g} / \mathrm{l}$. On the basis of cardiac dysfunction and on the background of congestion, the function of not only the liver but also the kidneys is impaired (the so-called cardiorenal syndrome in heart failure). This is indicated by an increase in urea and creatinine by 38.5 and $36.9 \%$, respectively, compared with animals in the control group. The use of the drug "Bendamin" alleviated the manifestations of functional failure of the heart, liver and kidneys, as indicated by biochemical studies. Studies confirm the feasibility of using the drug "Bendamin" in dogs with the development of heart failure. The use of the drug "Bendamine" in patients with heart failure in dogs had a positive effect on the restoration of hematopoiesis and the normalization of biochemical parameters of the blood.

Key words: pharmacology, bendamin, heart failure, cardiomyopathy, dogs.

\section{Вплив препарату “Бендамін” на біохімічні показники крові собак за серцевої недостатності}

\author{
I. С. Вархоляк, Б. В. Гутий
}

Львівський національний університет ветеринарної медицини та біотехнологій імені С. 3. Гжицького, м. Львів, Україна

Експериментальні дослідження, одержанні за останні роки, вказують на актуальність розробки лікарських засобів комплексної дї для попередження розвитку сериево-судинної патологї̈ у собак. Це вимагає значно глибшого вивчення патогенезу сериевої 
недостатності, в тому числі кардіоміопатії. Метою роботи було дослідити вплив препарату “Бендамін” на біохімічні показники крові собак за сериевої недостатності. Для проведення досліджень було сформовано дві групи собак: контрольну (здорові) і дослідну (хворі). У 30-денний дослід було включено 10 собак контрольної групи і 10 собак дослідної (хворі) породи спанієль та болонка 10-12 річного віку. Схема лікування хворих собак: фуросемід задавали перорально натще по 2 мг/кг кожні 12 год; еналаприл задавали перорально по 0.5 мг/кг кожні 12 год; бендамін задавали перорально натще по 20 мг/кг кожні 24 год. Рекомендовано ділити дозу на два прийоми. За сериевої недостатності у сироватці крові собак встановлено підвищення активності амінотрансфераз (АлАТ на 59,2 \%, АсАТ - на 51,9\%). При цььому встановлено і підвищення активності лужної фосфатази, ио у комплексі є додатковим підтвердженням змін з боку серцевого м'язу. Активність лактатдегідрогенази підвищилася у крові хворих собак на 23,5 \%. Незначні зміни вмісту загального білірубіну та сечовини у сироватці крові хворих собак вказують на початкову стадію розвитку патології печінки із порушенням ї̈ функиії внаслідок застійних явищ у малому колі кровообігу. На це також вказує зниження рівня загального протеїну у крові хворих собак, який відповідно становив 57,2 \pm 3,57 г/л проти контрольної групи 63,5 \pm 4,15 г/л. На основі порушення сериевої функції та на тлі застійних явищ порушується функція не лише печінки, а й нирок (так званий кардіоренальний синдром за сериевої недостатності). На ие вказує зростання вмісту сечовини та креатиніну відповідно на 38,5 та 36,9\% порівняно з тваринами контрольної групи. Застосування препарату “Бендамін” пом'якиувало прояви функціональної неспроможності серия, печінки, а також і нирок, на щзо вказують проведені біохімічні дослідження. Проведені дослідження підтверджують доцільність застосування препарату “Бендамін” собакам за розвитку серцевої недостатності. Застосування хворим на сериеву недостатність собакам кардіопрепарату “Бендамін” мало позитивний вплив на відновлення процесу кровотворення та нормалізацію біохімічних показників крові.

Ключові слова: фармакологія, бендамін, сериева недостатність, кардіоміопатія, собаки.

\section{Вступ}

Результати проведених досліджень та узагальнення даних літератури вказують на те, що понад $10 \%$ захворювань домашніх тварин припадає на частку серцево-судинних захворювань (Borgarelli et al., 2004; 2007; Borgarelli \& Buchanan, 2012; Reynolds et al., 2012; Hollmer et al., 2017). Варто зазначити, що серцеві захворювання у домашніх тварин не завжди проявляються клінічно, саме тому власники тварин найчастіше дізнаються про наявність захворювання серцевосудинної системи у свого улюбленця занадто пізно. За виявлення у тварин серцево-судинної патології важливим $є$ встановити ступінь розладів гемодинаміки, а також захворювання інших органів, що може бути вирішальним для перебігу та прогнозу (Cornell et al., 2004; Chetboul \& Tissier, 2012; Fox, 2012; LopezAlvarez et al., 2015; Larouche-Lebel et al., 2019).

Експериментальні дослідження, одержанні за останні роки, вказують на актуальність розробки лікарських засобів комплексної дії для попередження розвитку серцево-судинної патології у собак. Це вимагає значно глибшого вивчення патогенезу серцевої недостатності, в тому числі кардіоміопатії (Tilley et al., 2008; Merveille et al., 2015; Ramírez et al., 2016; Menciotti et al., 2017; Yata et al., 2019; Morgan et al., 2020).

Зважаючи на аналіз даних вітчизняних і зарубіжних дослідників, розробка зручного у застосуванні та безпечного комплексного кардіологічного препарату, використання якого дозволить підвищити ефективність лікування тварин і широкого спектру серцевосудинних патологій, є на часі (Undhad et al., 2012; Trofimjak \& Slivinska, 2016; Zhulikova, 2016). У цьому аспекті необхідно відзначити, що впровадження у практику ветеринарної медицини нових кардіологічних препаратів $є$ надзвичайно актуальним та перспективним. Серед кардіопрепаратів у ветеринарій медицині інтерес становлять засоби, виготовлені на основі пімобендану, оскільки його дія полягає у посиленні скоротливої здатності серця та відповідно покращенні трофіки. Завдяки наявності позитивної інотропної і вазодилатаційної дії при серцевій недостатності пі- мобендан підвищує силу серцевих скорочень і зменшує як переднавантаження, так і післянавантаження (Oldach et al., 2019; Tjostheim et al., 2019; Varcholyak \& Gutyi, 2019).

Враховуючи позитивні результати впливу пімобендану на організм тварин за розвитку серцевої недостатності для лікувально-профілактичних заходів цієї патології необхідно застосовувати препарати, що містять вказану вище діючу речовину (Trofimiak \& Slivinska, 2021).

На думку ряду науковців, первинні патогенетичні зрушення за формування патології серцево-судинної системи тісно взаємопов'язані 3 перенапруженням механізмів утилізації активних форм кисню і ступенем порушень у системі ПОЛ - АОС, та значною мірою визначаються станом імунної системи організмy (Keene et al., 2019). Їхній дисбаланс лежить в основі порушень метаболізму загалом, який значною мірою відбивається на стані клітинних мембран. Крім того, серед показників метаболізму за розвитку патології система ПОЛ - САЗ вирізняється ранніми відхиленнями (Martyshuk \& Gutyj, 2019; Nazaruk et al., 2021; Martyshuk \& Hutyi, 2021). Їм належить провідна роль як у процесах адаптації здорового організму до екстремальних умов, так і в розвитку значно глибоких порушень за патології (Martyshuk et al., 2016; 2018; 2019). Зокрема, вважається доведеним, що зміни в протіканні процесів ПОЛ є одним із патогенетичних механізмів розвитку серцево-судинної патології (Varkholiak et al., 2020).

Порушення системи антиоксидантного захисту організму собак під впливом токсичних речовин та корекція його при застосуванні різних комбінацій фармакологічних та природних антиоксидантів $є$ актуальним і своєчасним (Lavryshyn et al., 2016).

У ветеринарній медицині одним 3 найбільш перспективних препаратів групи антиоксидантів є похідні 3-оксипіридину, зокрема етилметилгідроксипіридин сукцинат - антиоксидант прямої дії. Механізм дії даного препарату полягає у антиоксидантній та мембранопротекторній дії (Varkholiak et al., 2020). Він пригнічує процеси пероксидного окиснення ліпідів та сприяє підвищенню активності супероксиддисмутази, 
яка нейтралізує пусковий радикал вільнорадикальних процесів. За умов ішемії тканин даний препарат посилює компенсаторну активацію аеробного гліколізу, а також знижує ступінь пригнічення окисних процесів у циклі Кребса та сприяе активізації синтезу АТФ. За впливу етилметилгідроксипіридину сукцинату встановлено зниження в кардіоміоцитах специфічного білка, що прискорює апоптоз. Також відбувається модулювання трансмембранних іонних струмів: сповільнюється повільний струм через кальцієві канали, відвертається блокада швидких натрієвих каналів та блокада швидко активованого компонента калієвого струму затриманого випрямлення (JKR) (Varkholiak \& Gutyj, 2018; 2019; Varkholiak et al., 2019; 2021).

Таким чином етилметилгідроксипіридину сукцинат проявляє комплексний вплив на метаболізм міокарда тварин.

Комбінований підхід для лікування тварин за серцевої недостатності, в основі якого лежить застосування інгібітора фосфодиестерази-3 та антиоксидантів, є актуальним. Оскільки антиоксидантні сполуки можуть захищати здорові клітини та тканини організму собак від розвитку небажаних побічних ефектів, викликаних розвитком серцевої недостатності. Крім того, відомо, що у розвитку даної патології характерним $є$ оксидативний стрес, який обумовлює особливу метаболічну активність антиоксидантів (Martyshuk, 2016; Varkholiak \& Gutyj, 2019).

Отже, застосування антиоксидантів у складі кардіопрепаратів за серцевої недостатності у собак може поліпшити окисно-відновну адаптацію клітин серцевого м'яза та вберегти їх від негативної дії вільних радикалів.

Метою роботи було дослідити вплив препарату "Бендамін" на біохімічні показники крові собак за серцевої недостатності.

\section{Матеріал і методи досліджень}

Для проведення досліджень було сформовано дві групи собак: контрольну (здорові) і дослідну (хворі). У 30-денний дослід було включено 10 собак контрольної групи і 10 собак дослідної (хворі) породи спанієль та болонка 10-12 річного віку.

За період 2016-2019 років, клінічно досліджено 567 собак. Тваринам було проведено неінвазивні методи досліджень (ехокардіографія, електрокардіографія, рентген грудної клітки), а також гематологічне та біохімічне дослідження крові. Було виявлено патології серця у 339 тварин. Серед порід собак, яким застосовували “Бендамін”. були такси (23 тварини), болонки (48 тварин), кокер-спаніелі (92), йоркширські тер'єри (108), пекінеси (18), лабрадори (15), голден ретривери (1), німецькі вівчарки (7), доберманипінчери (2), стаффордширські бультер'єри (4), метиси та інші породи (21).
Схема лікування хворих собак: фуросемід задавали перорально натще по 2 мг/кг кожні 12 год; еналаприл задавали перорально по 0.5 мг/кг кожні 12 год; бендамін задавали перорально натще по 20 мг/кг кожні 24 год. Рекомендовано ділити дозу на два прийоми.

У сироватці крові досліджували активність аланінамінотрансферази (АлАТ; К.Ф. 2.6.1.2.) і аспартатамінотрансферази (АсАТ; К.Ф. 2.6.1.1.) за методом Райтмана й Френкеля в модифікації К. Г. Капетанакі (1962); активність лужної фосфатази (ЛФ; К.Ф. 3.1.3.1.) - фотоколориметрично (Комаров Ф. І., 1981); активність лактатдегідрогенази (ЛДГ) (К.Ф.1.1.1.27) визначали колориметричним методом Шевела і Товарек. Визначення глюкози у крові проводили глюкозооксидазним методом. Концентрації Кальцію та Фосфору у сироватці крові проводили уніфікованими лабораторними методами (Vlizlo et al., 2012).

Протеїнсентизувальну функцію печінки визначали за рівнем у сироватці крові загального протеїну (біуретовою реакцією) і протеїнових фракцій (методом електрофорезу в поліакриламідному гелі) (Vlizlo et al., 2012).

Усі маніпуляції з тваринами проводили відповідно до Європейської конвенції про захист хребетних тварин, які використовуються для експериментальних і наукових цілей (Страсбург, 1986 р.).

Аналіз результатів досліджень проводили за допомогою пакету програм Statistica 6.0. Вірогідність різниць оцінювали за t-критерієм Стьюдента. Результати вважали вірогідними при $\mathrm{P} \leq 0,05$.

\section{Результати та їх обговорення}

За розвитку серцевої недостатності у собак встановлено зниження у сироватці крові рівня загального протеїну, де порівняно з контрольною групою собак він знизився на 9,9 \%. Також у хворих тварин встановлено зниження загального білірубіну, який у сироватці крові дослідної групи собак до лікування відповідно коливався у межах 3,3 \pm 0,25 мкмоль/л проти $3,7 \pm 0,31$ мкмоль/л контролю (табл. 1).

Серед ензимів, пов'язаних з обміном білка і амінокислот, важливе значення має активність аспартатамінотрансферази та аланінамінотрансферази. Рівень активності АлАТ та АсАТ, їх співвідношення в сироватці крові тварин змінюються за різних умов. Важливе діагностичне значення має надмірне зростання активності цих ензимів, яке виникає внаслідок руйнування клітин за порушення процесів обміну речовин при захворюваннях. Воно може бути спричинене різними патологічними чинниками. При дослідженні функціонального стану печінки у хворих на серцеву недостатність собак до лікування встановлено підвищення активності амінотрансфераз у їхній крові, де відповідно активність АлАТ підвищилася на 59,2 \%, а активність АсАТ - на 51,9 \% щодо показників контрольної групи. 


\section{Таблищя 1}

Біохімічні показники крові собак за розвитку серцевої недостатності та дії препарату “Бендамін” $(\mathrm{M} \pm \mathrm{m} ; \mathrm{n}=10)$

\begin{tabular}{|c|c|c|c|}
\hline \multirow{3}{*}{ Показники } & \multicolumn{3}{|c|}{ Групи тварин } \\
\hline & \multirow{2}{*}{ Контрольна } & \multicolumn{2}{|c|}{ Дослідна } \\
\hline & & до лікування & після лікування \\
\hline Загальний протеїн, г/л & $63,5 \pm 4,15$ & $57,2 \pm 3,57$ & $61,9 \pm 5,24$ \\
\hline Білірубін, мкмоль/л & $3,7 \pm 0,31$ & $3,3 \pm 0,25$ & $4,0 \pm 0,30$ \\
\hline АлАТ, од/л & $38,2 \pm 2,10$ & $60,8 \pm 3,54 * * *$ & $33,7 \pm 4,23$ \\
\hline АсAТ, од/л & $23,5 \pm 1,11$ & $35,7 \pm 1,58 * * *$ & $28,3 \pm 1,47 *$ \\
\hline ЛДГ, од/л & $80,4 \pm 4,54$ & $99,3 \pm 5,12 *$ & $93,2 \pm 4,86^{*}$ \\
\hline Лужна фосфатаза, од/л & $88,6 \pm 5,35$ & $108,2 \pm 6,25^{*}$ & $102,5 \pm 5,20 *$ \\
\hline Амілаза, од/л & $925 \pm 32,5$ & $756 \pm 28,7 * *$ & $852 \pm 30,4$ \\
\hline Креатинін, мкмоль/л & $95,3 \pm 4,88$ & $130,5 \pm 4,22 * * *$ & $100,4 \pm 5,12$ \\
\hline Сечовина, мкмоль/л & $6,5 \pm 0,41$ & $9,0 \pm 0,55^{* *}$ & $8,4 \pm 0,50 * *$ \\
\hline Холестерин, ммоль/л & $4,6 \pm 0,20$ & $5,8 \pm 0,22 * * *$ & $5,0 \pm 0,20$ \\
\hline Кальцій, ммоль/л & $2,51 \pm 0,14$ & $2,33 \pm 0,16$ & $2,40 \pm 0,16$ \\
\hline Фосфор, ммоль/л & $1,27 \pm 0,05$ & $1,48 \pm 0,09^{*}$ & $1,24 \pm 0,07$ \\
\hline Глюкоза, ммоль/л & $4,11 \pm 0,11$ & $3,77 \pm 0,14^{*}$ & $3,93 \pm 0,15$ \\
\hline
\end{tabular}

Після застосування препарату “Бендамін” встановлено зниження активності амінотрасфераз у сироватці крові дослідних собак порівняно з показниками, взятими ще до лікування, де відповідно активність вказаних ензимів становила $33,7 \pm 4,23$ і 28,3 $\pm 1,47$ од/л.

До групи ензимів фосфатаз належить лужна фосфатаза, яка бере участь у каталізі фосфорних ефірів у плазмі крові та у тканинах. Крім того, вона міститься також в епітеліальних клітинах стінок тонкого відділу кишечнику, печінки, кістковій тканині та лейкоцитах. Важливість дії цього ензиму у тварин полягає ще й у тому, що лужна фосфатаза бере активну участь в обміні Кальцію та неорганічного Фосфору в їх організмі. Встановлено, що у собак дослідної групи, в яких були характерні клінічні ознаки серцевої недостатності, встановлено підвищення активності даного ензиму на 22,1 \%. Після лікування тварин встановлено зниження у крові собак дослідної групи активності лужної фосфатази, однак порівняно 3 показниками контрольної групи активність ензиму була нижчою на 15,7 \% відповідно.

Одним із найважливіших ензимів, які беруть участь в обміні вуглеводів, є лактатдегідрогеназа, що здійснює відновлення піровиноградної кислоти до молочної. Цей цинквмісний ензим належить до класу оксидоредуктаз і складається із 4-х поліпептидних субодиниць 2-х типів. Дослідження активності ЛДГ в сироватці крові собак показало, що за розвитку серцевої недостатності в організмі піддослідних тварин відбулися певні зміни та спостерігалися деякі відмінності між тваринами контрольної групи собак. Встановлено, що найвищою активність ЛДГ була у сироватці крові дослідної групи собак до лікування, де порівняно 3 показниками контрольної групи собак вона підвищилася на 23,5 \%. Дещо нижчою активність досліджуваного ензиму була у сироватці крові собак дослідної групи після лікування, де відповідно вона була в межах 93,2 \pm 4,86 од/л.

При визначенні активності амілази у сироватці крові собак встановлено, що в контрольної групи собак вона становила $925 \pm 32,5$ од/л, тимчасом як у хворих собак до лікування активність амілази знизилася на 18,3 \% та після лікування - на 8,0 \% відповідHo.

Рівень сечовини у крові дослідної групи собак до лікування зріс на 38,5 \%, тимчасом як після проведеного курсу лікування рівень сечовини дещо знизився порівняно 3 початком досліду, однак залишався вищим на 29,2 \% порівняно 3 показниками контрольної групи собак.

Як сечовина, так і креатинін - показники роботи нирок, які беруть участь в енергетичному обміні тканин. Встановлено, що рівень креатиніну у сироватці крові дослідної групи собак також вірогідно зростав до $130,5 \pm 4,22$ мкмоль/л, тимчасом як у контрольної групи собак даний показник становив $95,3 \pm 4,88$ мкмоль/л. Після проведеного лікування рівень креатиніну у сироватці крові дослідної групи собак знизився на 23,1 \% порівняно з показниками, взятими у даної групи собак до лікування.

Аналогічні зміни спостерігаємо і при дослідженні рівня холестерину, який також у сироватці крові дослідної групи тварин зростав на 26,1 і 8,7 \% щодо контрольної групи.

Глюкоза в організмі собак виконує функцію джерела енергії та $є$ субстратом для багатьох хімічних реакцій. Вона $є$ основним субстратом енергетичного обміну. Глюкоза та їі похідні наявні в більшості органів і тканин. Концентрація глюкози в крові залежить від активності процесів глікогенезу, глікогенолізу, глюконеогенезу i гліколізу. Згідно 3 проведеними дослідженнями встановлено, що у сироватці крові контрольної групи собак рівень глюкози всередньому становив 4,11 \pm 0,11 ммоль/л, тимчасом як у дослідної групи даний показник мав тенденцію до зниження. Так, до лікування у хворих собак дослідної групи рівень глюкози знизився на 8,3\%, а після лікування на 4,4 \% відповідно.

У хворих на серцеву недостатність тварин аналіз величин вмісту Кальцію в сироватці крові собак дослідної групи показав, що він на початку досліду істотно знижувався на 7,2 \% щодо показників контроль- 
ної групи, тимчасом як після лікування рівень даного показника у сироватці крові собак дослідної групи становив 2,40 $\pm 0,16$ ммоль/л.

Варто зазначити, що динаміка змін вмісту Фосфору була зворотною. Так, відповідно на початку досліду рівень Фосфору у крові дослідної групи собак вірогідно підвищився на 14,2 \% щодо показників крові собак контрольної групи. Після проведеного лікування, де використовували новий кардіопрепарат “Бендамін”, рівень Фосфору у крові дослідної групи дещо знизився, де відповідно становив 1,24 $\pm 0,07$ ммоль/л.

Таким чином, на основі проведених досліджень встановлено, що у собак за розвитку серцевої недостатності відбуваються зміни біохімічних показників крові.

\section{Висновки}

Проведені дослідження підтверджують доцільність застосування препарату "Бендамін” собакам за розвитку серцевої недостатності. Застосування хворим на серцеву недостатність собакам кардіопрепарату "Бендамін” мало позитивний вплив на відновлення процесу кровотворення та нормалізацію біохімічних показників крові.

Перспективи подальших досліджень. У подальшому планується дослідити вплив препарату "Бендамін" на стан неензимної ланки системи антиоксидантного захисту організму собак за серцевої недостатності.

Відомості про конфлікт інтересів. Автори стверджують про відсутність конфлікту інтересів щодо їх вкладу та результатів досліджень.

Подяка. Ця робота була фінансово підтримана Міністерством освіти і науки України (0120U101999).

\section{References}

Borgarelli, M., \& Buchanan, J. W. (2012). Historical review, epidemiology and natural history of degenerative mitral valve disease. Journal of Veterinary Cardiology, 14(1), 93-101. doi: 10.1016/j.jvc.2012.01.011.

Borgarelli, M., Tarducci, A., Zanatta, R., \& Haggstrom, J. (2007). Decreased systolic function and inadequate hypertrophy in large and small breed dogs with chronic mitral valve insufficiency. Journal of Veterinary Internal Medicine, 21(1), 61-67. doi: 10.1892/08916640(2007)21[61:dsfaih]2.0.co;2.

Borgarelli, M., Zini, E., D’Agnolo, G., Tarducci, A., Santilli, R. A., Chiavegato, D., Tursi, M., Prunotto, M., \& Häggström, J. (2004). Comparison of primary mitral valve disease in German Shepherd dogs and in small breeds. Journal of Veterinary Car-diology, 6(2), 27-34. doi: 10.1016/S1760-2734(06)70055-8.

Chetboul, V., \& Tissier, R. (2012). Echocardiographic assessment of canine degenerative mitral valve disease. Journal of Veterinary Cardiology, 14(1), 127148. doi: 10.1016/j.jvc.2011.11.005.

Cornell, C. C., Kittleson, M. D., Torre, P. D., Haggstrom, J., Lom-bard, C. W., Pedersen, H. D., Vollmar, A., \&
Wey, A. (2004). Allometric scaling of M-mode cardiac measurements in normal adult dogs. Journal of Veterinary Internal Medicine, 18(3), 311-321. doi: 10.1892/0891-6640(2004)18<311:asomcm>2.0.co;2.

Fox, P. R. (2012). Pathology of myxomatous mitral valve disease in the dog. Journal of Veterinary Cardiology, 14(1), 103-126. doi: 10.1016/j.jvc.2012.02.001.

Hollmer, M., Willesen, J. L., Tolver, A., \& Koch, J. (2017). Left atrial volume and function in dogs with naturally occurring myxomatous mitral valve disease. Journal of Veterinary Car-diology, 19(1), 24-34. doi: 10.1016/j.jvc.2016.08.006.

Keene, B. W., Atkins, C. A., Bonagura, J. D., Fox, P. R., Hägg-ström, J., Fuentes, V. L., Oyama, M. A., Rush, J. E., Stepien, R., \& Uechi, M. (2019). ACVIM consensus guidelines for the diagnosis and treatment of myxomatous mitral valve disease in dogs. Journal of Veterinary Internal Medicine, 33(3), 1127-1140. doi: 10.1111 jvim. 15488 .

Larouche-Lebel, E., Loughran, K. A., \& Oyama, M. A. (2019). Echocardiographic indices and severity of mitral regurgitation in dogs with preclinical degenerative mitral valve disease. Journal of Veterinary Internal Medicine, 33(2), $489-498$. doi: 10.1111 jvim. 15461 .

Lavryshyn, Y. Y., Varkholyak, I. S., Martyschuk, T. V., Guta, Z. A., Ivankiv, L. B., Paladischuk, O. R., Murska, S. D., Gutyj, B. V., \& Gufriy, D. F. (2016). The biological significance of the antioxidant defense system of animals body. Scientific Messenger LNUVMBT named after S.Z. Gzhytskyj, 18, 2(66), 100-111. doi: 10.15421/nvlvet6622.

Lopez-Alvarez, J., Elliott, J., Pfeiffer, D., Chang, Y.-M., Mattin, M., Moonarmart, W., Hezzell, M.J., \& Boswood, A. (2015). Clinical Severity Score System in Dogs with Degenerative Mi-tral Valve Disease. Journal of Veterinary Internal Medicine, 29(2), 575581. doi: 10.1111/jvim.12544.

Martyshuk, T. V. (2016). The influence of oxidative stress on the state of the antioxidant defense system in the organism of rats. Regulatory Mechanisms in Biosystems, 7(1), 8-12. doi: 10.15421/021602.

Martyshuk, T. V., \& Hutyi, B. V. (2021). Imunofiziolohichnyi stan ta antyoksydantnyi potentsial orhanizmu porosiat za umov oksydatsiinoho stresu ta dii koryhuiuchykh chynnykiv: monohrafiia. Lviv: SPOLOM (in Ukrainian).

Martyshuk, T. V., Gutyj, B. V., \& Vishchur, O. I. (2016). Level of lipid peroxidation products in the blood of rats under the influence of oxidative stress and under the action of liposomal preparation of "Butaselmevit", Biological Bulletin of Bogdan Chmelnitskiy Melitopol State Pedagogical University, 6(2), 22-27. doi: 10.15421/201631.

Martyshuk, T. V., Gutyj, B. V., \& Vishchur, O. I. (2018). Indicators of functional and antioxidant liver status of rats under oxidative stress conditions and on the action of the liposomal drug "Butaselmevit". Scientific Messenger of Lviv National University of Veterinary Medicine and Biotechnologies, 20(89), 100-107. doi: $10.32718 /$ nvlvet8919. 
Martyshuk, T. V., Gutyj, B. V., Vishchur, O. I., \& Todoriuk, V. B. (2019). Biochemical indices of piglets blood under the action of feed additive "Butaselmevitplus". Ukrainian Journal of Veterinary and Agricultural Sciences, 2(2), 27-30. doi: 10.32718/ujvas2-2.06.

Martyshuk, T., \& Gutyj, B. (2019). Influence of feed additive "Butaselmevit-Plus" on antioxidant status of rats in conditions of oxidative stress. Scientific Messenger of LNU of Veterinary Medicine and Biotechnologies. Series: Agricultural Sciences, 21(90), 76-81. doi: 10.32718/nvlvet-a9013.

Menciotti, G., Borgarelli, M., Aherne, M., Wesselowski, S., Haggstrom, J., Ljungvall, I., Lahmers, S. M., \& Abbott, J. A. (2017). Mitral valve morphology assessed by three-dimensional transthoracic echocardiography in healthy dogs and dogs with myxomatous mitral valve disease. Journal of Veterinary Cardiology, 19(2), 113 123. doi: 10.1016/j.jvc.2017.01.002.

Merveille, A.-C., Bolen, G., Krafft, E., Roels, E., Gomart, S., Etienne, A.-L., Clercx, C., \& Entee, K. Mc. (2015). Pulmonary Vein-to-Pulmonary Artery Ratio is an Echocardiographic Index of Congestive Heart Failure in Dogs with Degenerative Mitral Valve Disease. Journal of Veterinary Internal Medicine, 29(6), 1502 1509. doi: 10.1111/jvim.13634.

Morgan, K. R. S., Monteith, G., Raheb, S., Colpitts, M., \& Fonfara, S. (2020). Echocardiographic parameters for the assessment of congestive heart failure in dogs with myxomatous mitral valve disease and moderate to severe mitral regurgitation. The Veterinary Journal, 263, 1-25. doi: 10.1016/j.tvj1.2020.105518.

Nazaruk, N. V., Gutyj, B. V., Gufrij, D. F., Leskiv, Kh. Ya., Ivashkiv, R. M., \& Martyshuk, T. V. (2021). The effect of methyphen and vitamix se on the level of products of bull lipid peroxide oxidation under nitratecadmium load. Colloquium-journal, 7(94), 16-18. doi: 10.24412/2520-6990-2021-794-16-18

Oldach, M. S., Ueda, Y., Ontiveros, E. S., Fousse, S. L., Harris, S. P., \& Stern, J. A. (2019). Cardiac Effects of a Single Dose of Pimobendan in Cats With Hypertrophic Cardiomyopathy; A Randomized, Placebo-Controlled, Crossover Study. Front Vet Sci., 6, 15. doi: 10.3389/fvets.2019.00015.

Ramírez, V. L., Berrío, A., \& Arias, M. P. (2016). Correlation between the clinical stage, echocardiographic findings and systemic blood pressure in dogs with Degenerative Disease of the Mitral Valve. CES Veterinary medicine and y Zootechnics, 11(2), 61-72. doi: 10.21615/cesmvz.11.2.5.

Reynolds, C. A., Brown, D. C., Rush, J. E., Fox, P. R., Nguyenba, T. P., Lehmkuhl, L. B., Gordon, S. G., Kellihan, H. B., Stepien, R. L., Lefbom, B. K., Meier, C. K., \& Oyama, M. A. (2012). Prediction of first onset of congestive heart failure in dogs with degenerative mitral valve disease: The PREDICT cohort study. Journal of Veterinary Cardiology, 14(1), 193-202. doi: 10.1016/j.jvc.2012.01.008.

Tilley, P. L., Francis, W. K., Smith, J., Oyama, M.A. (2008). Manual of canine and feline cardiology. Copyright by Saunders, an imprint of Elsevier Inc, 105-106 (Fourth edition).
Tjostheim, S. S., Kellihan, H. B., Grint, K. A., \& Stepien, R. L. (2019). Effect of sildenafil and pimobendan on intracardiac heartworm infections in four dogs. J Vet Cardiol., 23, 96-103. doi: 10.1016/j.jvc.2019.02.001.

Trofimiak, R., \& Slivinska, L. (2021). Diagnostic value of echocardiographic indices of left atrial and ventricular morphology in dogs with myxomatous mitral valve disease (MMVD). Ukrainian Journal of Veterinary and Agricultural Sciences, 4(1), 16-23. doi: 10.32718/ujvas4-1.04.

Trofimjak, R., \& Slivinska, L. (2016). Diagnosis of chronic heart failure dogs - existing methods and future prospects. Scientific Messenger of LNU of Veterinary Medicine and Biotechnologies. Series: Veterinary Sciences, 18(71), 130-133. doi: $10.15421 /$ nvlvet7129.

Undhad, V. V., Fefar, D. T., Jivani, B. M., Gupta, H., Ghodasara, D. J., Joshi, B. P. \& Prajapati, K. S. (2012). Cardiac troponin: an emerging cardiac biomarker in animal health. Vet. World, 5, 508-511. doi: 10.5455/vetworld.2012.508-511.

Varcholyak, I. S., \& Gutyi, B. V. (2019). Determination of the chronic toxicity of preparation "Bendamin" on laboratory animals. Theoretical and Applied Veterinary Medicine, 7(2), 63-68. doi: 10.32819/2019.71011.

Varkholiak, I. S., \& Gutyj, B. V. (2018). Determination of acute toxicity of "Bendamin" drug in laboratory animals. Scientific Messenger of Lviv National University of Veterinary Medicine and Biotechnologies, 20(92), 209-212. doi: $10.32718 /$ nvlvet9243.

Varkholiak, I. S., \& Gutyj, B. V. (2019). The degree of cumulation of the "Bendamin" drug in the body of white rats. Scientific Messenger of Lviv National University of Veterinary Medicine and Biotechnologies. Series: Veterinary sciences, 21(94), 82-85. doi: 10.32718/nvlvet9415.

Varkholiak, I. S., Gutyj, B. V., Leskiv, Kh. Ya., Kushnir, V. I., Hariv, I. I., Martyshuk, T. V., \& Guta, Z. A. (2021). The effect of bendamine on antioxidant protection of rats' myocardium in doxorubicin intoxication. Colloquium-journal, 7(94), 18-21. doi: 10.24412/2520-6990-2021-794-18-21

Varkholiak, I. S., Gutyj, B. V., Leskiv, Kh. Ya., Kushnir, V. I., Hariv, I. I., Martyshuk, T. V., \& Guta, Z. A. (2021). The effect of bendamine on antioxidant protection of rats' myocardium in doxorubicin intoxication. Colloquium-journal, 7(94), 18-21. doi: 10.24412/2520-6990-2021-794-18-21.

Varkholiak, I., Gutyj, B., \& Leskiv, Kh. (2020). Influence of "Bendamin" on the indices of antioxidant protection in rat's blood by an experimental doxorubicininduced cardiomyopathy. Scientific Light, 35, 41-44.

Varkholiak, I., Gutyj, B., Kushnir, V., Nazaruk, N., Lisnyak, O., \& Yurynets, T. (2020). The effect of bendamine on the intensity of lipid peroxidation and the activity of the antioxidant defense system of blood in rats in experimental doxorubicin-induced cardiomyopathy. Scientific Messenger of LNU of Veterinary Medicine and Biotechnologies. Series: Veterinary Sciences, 22(100), 36-40. doi: 10.32718/nvlvet10007. 
Vlizlo, V. V., Fedoruk, R. S., \& Raty`ch, I. B. (2012). Laboratorni metody' doslidzhen' $u$ biologiyi, tvary`nny`cztvi ta vetery`narnij medy`cy`ni: dovidny'k. L`viv: Spolom (in Ukrainian).

Yata, M., Kooistra, H. S., \& Beijerink, N. J. (2019). Cardiorenal and endocrine effects of synthetic canine BNP1-32 in dogs with compensated congestive heart failure caused by myxomatous mitral valve disease. J Vet Intern Med., 33(2), 462-470. doi: 10.1111/jvim.15416.
Zhulikova, O. A. (2016). Monitoring rasprostranenija serdechno-sosudistyh zabolevanij sredi koshek i sobak v g. Blagoveshhensk amurskoj oblasti. Dal'nevostochnyj agrarnyj vestnik, 2(38), 49-56. https://cyberleninka.ru/article/n/monitoringrasprostraneniya-serdechno-sosudistyh-zabolevaniysredi-koshek-i-sobak-v-g-blagoveschensk-amurskoyoblasti (in Russian). 